\title{
The virtual canon: \\ Don Quixote in the Spanish Cyberland ${ }^{1}$
}

\author{
Dolores Romero López \\ Universidad Complutense de Madrid \\ dromero@filol.ucm.es
}

\section{Introduction}

We are at a historic moment in which it seems that everything is changing from paper to computer, from analogue to digital. The canonical texts, once digitized, acquire, thanks to the Web, a global dimension. We must think about the model followed in this transfer of knowledge and its historical and literary consequences. In this article we, firstly, select a canonical and universal text, Don Quixote and, secondly, we search and analyze how the text has been transferred to digital format online. Finally, we will try to see what specific features offer the digitization of canonical books.

When, in year 2005, the 4th Centenary of the publication of Don Quixote was celebrated in Spain, it was necessary to analyze how the myth of Don Quixote was being re-read from the Spanish culture perspective since the beginning of the century. It is clear the importance of Don Quixote as a meme (Dawkins, 1979), that is, as a cultural and theoretical unity that can be transmitted between individuals over time. Jesús Mosterín in the ninth chapter of her book La cultura humana (2009) affirms that the culture of an individual in a given time would be present in his/her brain memes set. The vague

\footnotetext{
${ }^{1}$ All the email addresses have been verified on October 30, 2010. This work has been developed for two research projects subsidized by the Ministry of Science and Technology: The titles of these projects are: "Escritorios electrónicos para las literaturas" y "El otro Parnaso: falsificaciones literarias españolas".
} 
notion of culture in a social group is analysed by Jesús Mosterín through several, precise, and different notions, defining all of them on the basis of the memes which are present in the brains of the members of the group (2009: 166-184).

Don Quixote is the most significant literary meme in Spanish culture. Don Quixote has been studied previously as meme by Dra Ben-Porat $(1978,2007)$ on the CULTS project in which, leveraging the digital revolution, the new literacy and the new mode of knowledge acquisition, she revived those canonical texts which are still considered a prerequisite to achieve an active cultural memory. Technically speaking this approach develops the classics thematic constellations based on neural networks in order to give charm to the threatened canon and make it more attractive to the generation of Web browsers and Internet users.

If Don Quixote has been a canonical book in universal and Spanish literature, it is not due to the fact that it was selected by Harold Bloom in The Western Canon but to the double capacity that it possesses, as on one hand, it can adjust itself to the values of each time, and, on the other hand, it can last as reading material thanks to the ideals of fighting, freedom and justice that pervade all its adventures.

In 1898 Spain lost its last colonies. All histories of literature talk about a "Crisis" to explain a historic time when the nation ceased to be a world power and withdrew into itself to rethink itself. At that time young writers, who were to reach universal fame later, took up again the myth of Don Quixote to face this difficult situation. On the occasion of the $3^{\text {rd }}$ Centenary of the appearance of the book, several revised versions of Don Quixote were published in Spain. I am just going to mention two of them. In 1905 Miguel de Unamuno published his Vida de D. Quijote y Sancho según Miguel de Cervantes [The Life of Don Quixote and Sancho according to Miguel de Cervantes] and Antonio Martínez Ruiz "Azorín" published La ruta de Don Quijote [The 
Route of Don Quixote]. Don Quixote in this novels is not a Baroque knight in search of adventures, but a knight looking for the faith in the human being, who goes through the villages of Spain at the end of the century in order to awaken people to the heroic spirit of its glorious past.

Today, in 2010, five years after the multiple celebrations on the occasion of the 4th Centenary of the publication of Don Quixote, we can make an assessment of what the re-readings of the literary myth have been like in the early 21 st century.

1.- Don Quixote has been re-read with special attention to women. The works of Fanny Rubio (2005), Daniel Gómez Cullá (2006) and Charlotte Lennox (2004) highlight the Cervantine phylogeny which collides into the $17^{\text {th }}$-Century misogyny. They revitalize the independence, restlessness, individualism, passion, strength of Dorotea, of Juana (Sancho's wife), of Maritornes, of Luscinda, of Camila, of Leandra..., all of them surpass the idealism of Dulcinea del Toboso. She was the prevailing image of the Don Quixote woman, the product of a romantic re-reading of the work. By contrast, at the beginning of the $21^{\text {st }}$ century, studies focus on other women with values that are better adjusted to our era.

2.- The second re-reading of Don Quixote is based on interculturality. The works of Roberto Monforte (2007), of Amelia Sanz Cabrerizo (2006), of Isabel Colón, García Carcedo (2005) and of Bárbara Fuchs $(2001,2003)$ highlight another key idea for the current question of cultural identity: the very structure of this work is articulated by intertwining pathways in Don Quixote. Such a rereading was presented in many classrooms with a view to teaching the value of dialogue to children and teenagers.

The story of Don Quixote is based on a journey from a small place in central Spain to the city of Barcelona. Inevitably Don Quixote comes across and meets many people from different social backgrounds (goat-keepers, shepherds, inn-keepers, farmers, 
barbers, galley slaves, millers, fishermen, actors, students, priests, college graduates, knights, dukes) and from different origins (Biscaians, Galicians, Moors) and we find even a blending between religions. Don Quixote never boasts about his "cleanliness of blood", perhaps because, as some biographers believe, Cervantes was a converted Jew and, therefore, rejected the discrimination against new Christians. Let us not forget that Cervantes hides behind Cid Hamet Benengeli, author of the manuscript written in Arabic, or perhaps "in an even older language", a possible reference to Hebrew, which would not have been strange in Toledo, where Crypto-Jews still spoke it.

The most striking point of this intercultural focus is that interculturality is not presented as a synthesis of opposites (Poor vs. Rich; Christian vs. Muslim; Spanish vs. Arabic-Hebrew) but as plural dualities that the novel explores as spaces of representation through difference. This double re-reading (women/interculturality) of Don Quixote has to be interpreted within the theoretical context of the validity of the so-called Cultural Studies.

However, from my point-of-view, there is a third space of rereading and revitalization of this canonical text: digital space.

\section{Don Quixote in cyberspace}

After a thorough analysis of the tracks left by Don Quixote on the Internet, I can venture to say that the digital Quixote enjoys good virtual health. We are gradually overcoming the conflict between apocalyptic and integrated intellectuals. It seems that even the critics most conversant with the text have agreed to offer digital versions of their own editions in the aim of reaching the anxiously desired "global reader".

Don Quixote has been able to transfer to Web many universal and canonical values (fight for freedom, justice and his ongoing defense of idealism). Scholars, readers, viewers, creators, critics, 
teenagers and children have helped make Don Quijote a true macromeme forward-looking text, image and sound. This is to demonstrate the strength of the associative thinking Vannemar Bush proposed in his classic article "As we may think" (1945). He imagined - before there were any computers to use as models - a machine called a memex, which would allow researchers to flexibly and interactively follow mental associations that came up in the process of inquiry. Therefore Vannemar Bush's Memex and the Meme described by Richard Dawkins in 1976 seem to converge seeking the mimesis, memory, flexibility and interactivity in the digital format.

\section{Don Quixote in digital texts}

The step from workbook format paper to e-book has led to a series of changes that affect both the materiality of the text of Don Quixote and its dissemination and receipt.We will gradually overcoming the confrontation between apocalyptic and integrated, i.e. among those readers that portend the death of the book by using the electronic format and those who expect that the new model of digital transmission is the beginning of an era in which any text can be consulted, read or referred to by the global reader.

There is a fact that draws attention to analyze the evolution from manuscript to the digital book. This is the Western culture passion for collecting knowledge to create education and culture. So far the literary memory had been archived on the shelves of libraries. Cyberspace has come to release many of these works and make them available to the global reader.

Don Quixote has become also a digital book and in recent years we have digitally compiled most of its editions. The first adventure of Don Quixote in the Internet came with the Web 1.0, created for the reading of texts. The example of Don Quixote is paradigmatic of what has been done and what we still could do. In this first stage (Lucia Mejías, 2010) we note that the Hypertext is still attached to shapes 
and characteristics of the printed books and ecdotic models from 19th century scientists. In the same way that the early printed books mimic external forms of manuscripts codices, thus the digital textual proposals attempt to mimic the printed books.

These Don Quixote editions are included in digital libraries either virtual or textual (Lucia Mejías, 2010). The most interesting spaces discussed below is that they have been upgraded along the years. They have gone from being the Web.1 spaces to turn into Web.2 spaces, with more textual flexibility and greater interactivity.

a) .- [The Miguel de Cervantes Virtual Library ] "La Biblioteca Virtual Miguel de Cervantes"2 has a Portal dedicated to the author ${ }^{3}$. There is access to the first editions of both parts. It is a real privilege for any philologist to visualize this treasure of the Spanish culture.

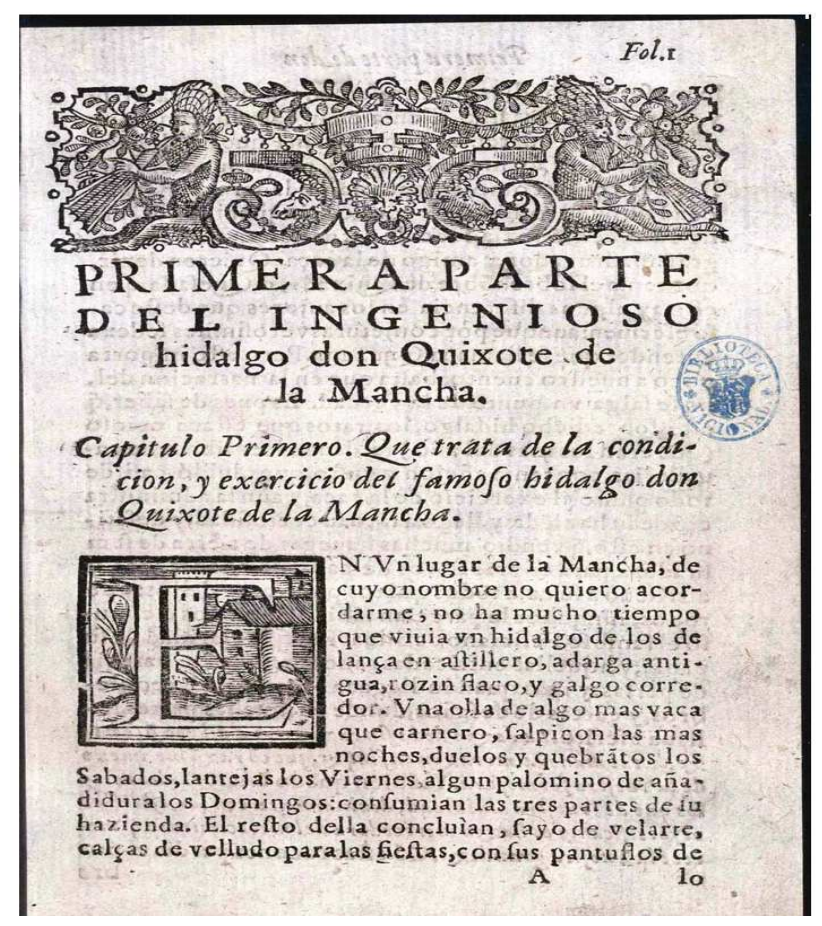

F.1: First edition of Don Quijote on line.

\footnotetext{
${ }^{2}<$ www.cervantesvirtual.com $>$

${ }^{3}$ http://www.cervantesvirtual.com/bib_autor/Cervantes/
} 
b) La "Biblioteca Digital Hispánica" [Hispanic Digital Library]", located in the Portal of Spain's National Library [Biblioteca Nacional de España]. On October 26, 2010 was presented at the National Library of Spain El Quijote interactivo ${ }^{5}$. This new version adds functionality to the previous ones, as for example, a high-quality zoom search on the text, the possibility of sharing a fragment on Facebook and listening to epoch music. This project enables user to deepen further the experience of Don Quixote and at the time that was published with several interactive content: books of chivalry, an approach to life in the $17 \mathrm{TH}$ century, or an interactive map. This interactive version incorporates allows to overlay and compare the transcript adapted to modern Spanish with the original text of the 17 TH century.

Para ver esta película, debe
disponer de QuickTime

un descompresor .

F.2 El Quijote interactivo, 2010

\footnotetext{
${ }^{4}<$ www.bne.es/es/Catalogos/BibliotecaDigital/index.html>

${ }^{5}$ http://quijote.bne.es/libro.html
} 
c) El "Centro Virtual Cervantes"6 [Cervantes Virtual Center] offers an on-line edition of Don Quixote prepared by one of its best specialists, Dr. Francisco Rico ${ }^{7}$.

d) The portal Google Libros ${ }^{8}$ [Google books] gives access to several editions of Cervantes's book. It is necessary to put the emphasis on the copy of the 1615 edition of the second part which is kept at the Hispanic Society of America and on a long list of later editions, mainly the ones which appeared in the $19^{\text {th }}$ and $20^{\text {th }}$ centuries. What makes "Google books" interesting is that it allows the general public to see the versions of Don Quixote that are found in North-American Universities.

e) [Cervantes Project] Proyecto Cervantes ${ }^{9}$ in which the Texas University and the Cervantes Chair of the University of Castilla-La Mancha collaborate. Its objective is to publish an electronic variorum edition of Don Quixote in the shape of a hypertextual archive with the creation of computer programmes and tools that will make it possible to edit and consult texts kept in multiple copies and with multiple variants.

f) In [Cybertext Collection] Colección Cibertextos ${ }^{10}$ made from the University of Duke by Miguel Garci-Gómez we find the most interactive edition of Don Quixote, with a prologue and notes by Diego Clemencín.

Of course there are many digital spaces where Don Quixote in Spanish and other languages editions are available ${ }^{11}$.In these specialized Libraries and Portals we observe that the first digital ecdotic approach of Don Quixote is dominated by a form of presentation that takes its inspiration from the printed book. As the

\footnotetext{
${ }^{6}$ http://cvc.cervantes.es/

7 http://cvc.cervantes.es/obref/quijote/

$8<$ books.google.es/books?hl=es>

${ }^{9}$ http://cervantes.tamu.edu/V2/CPI/index.html

${ }^{10}$ http://mgarci.aas.duke.edu/celestina/CERVANTES-MD/DON-QUIJOTE/

${ }^{11}$ http://www.cervantesvirtual.com/bib_autor/Cervantes/traducciones.shtml.
} 
software has evolved, these virtual spaces have gradually included computing tools that allow us to analyze the work: concordance listings, word search, morphological analysis and even translations into several languages.

\section{Don Quixote in Digital Images}

From its very conception, Don Quixote was an illustrated book. This is what Cervantes lets us know. The story of the ingenious knight already contained a few illustrations in its primitive version in Arabic. During the Alcana of Toledo episode of the discovery of the papers that allowed the story to be continued, we find a description of the way the fight of Don Quixote against the Biscaian had been painted. Below the characters, their names could be read and it is possible to see what each one was like. This paragraph, which I will not read out to you now for want of time, is the basis of Don Quixote's iconography. In it, Don Quixote is described with his "Rocinante" and Sancho with his donkey, just like we know them today. En el capítulo 9 de la primera parte leemos:

Estaba en el primer cartapacio pintada muy al natural la batalla de Don Quijote con el vizcaíno, puestos en la misma postura que la historia cuenta, levantadas las espadas, el uno cubierto de su rodela, el otro de la almohada, y la mula del vizcaíno tan al vivo, que estaba mostrando ser de alquiler a tiro de ballesta. Tenía a los pies el vizcaíno un título que decía: Don Sancho de Azpeitia que sin duda debía de ser su nombre, y a los pies de Rocinante estaba otro, que decía: Don Quijote: estaba Rocinante maravillosamente pintado, tan largo y tendido, tan atenuado y flaco, con tanto espinazo, tan hético confirmado, que mostraba bien al descubierto con cuánta advertencia y propiedad se le había puesto el nombre de Rocinante. Junto a él estaba Sancho Panza, que teía del cabestro a su asno, a los pies del cual estaba otro rótulo, que decía: Sancho Zancas; y debía de ser que tenía, a lo que mostraba la pintura, la barriga grande, el talle corto, y las zancas largas, y por esto se le debió de poner nombre de Panza y Zancas, que con estos dos sobrenombres se le llama algunas veces la historia. Otras algunas menudencias había que advertir; pero todas son de poca importancia y que no hacen al caso a la 
verdadera relación de la historia, que ninguna es mala como sea verdadera. (I.9)

Don Quixote has been an illustrated book since its first steps in the 17th century to our days (José Manuel Lucía Megías, 2005, 2006). The first pictures, of a stereotyped and impersonal nature, already appear in the 1605 Lisbon editions, and in the 1617 English edition we observe a more sophisticated, meticulous and courtly style.

To a large extent the canonization of Don Quixote as reading material came from its illustrations. A summary review of the editorial history of Don Quixote precisely reveals the tendency of pictures to replace words. Part of the plot lies in the constant desire to make Don Quixote's visual perceptions become reality, from these mills/giants to this Aldonza/Dulcinea. Such a desire to materialize ideals constitutes the subject matter of the novel and governs its structure as a parody.

A first analysis of the process of canonization of Don Quixote on the net allows us to confirm the existence of the same tendency towards canonization of the text through virtualized image. As a parallel to the edition of the text, most of the title-pages and drawings that adorned these editions have been virtualized. The most significant projects that are being carried out about images of Don Quixote are the following (Alvar and Lucía Megías, 2004).

1.- [The Cervantes Project] El Proyecto Cervantes ${ }^{12}$ (TexasCastilla-La Mancha) has created a documented electronic database taking the shape of a hypertextual archive with illustrations from Don Quixote. They claim that they can digitize as many as 20,000 pictures from different collections (iconography, ex libris, portraits).

\footnotetext{
${ }^{12}$ http://hera.uclm.es:8080/cervantes/iconography/equipo.html\#top
} 
2.- [Don Quixote popular iconography] Iconografía Popular de Don Quijote ${ }^{13}$ initiated by the [Study Center of Castilla-La Mancha] Centro de Estudios de Castilla-La Mancha which analyzes the popular contribution and vision of Don Quixote through materials such as collections of picture cards, postcards, calendars, comics, and so on.

3.- [The picture bank of Don Quixote: 1605-1905] El Banco de imágenes del Quijote: $1605-1905^{14}$ is a Project of the [Cervantine Study Center] Centro de Estudios Cervantinos ${ }^{15}$ in which several libraries, foundations and museums collaborate. This bank of pictures makes several types of research possible:

1) Theme search: through characters (Cervantes, D. Quixote or Sancho Panza), main characters (Priest, Dulcinea, the Knight of the White Moon), other characters (Grisóstomo or Marcela...), the world of knights (Castle, enchantment, Quixotic places and objects, reading, shaving-bowl, alcaná [marketplace], library).

2) Guided search: allows to access pictures according to the episode, draughtsman, engraver or library.

3) Expert search: allows access to a particular picture that is known beforehand.

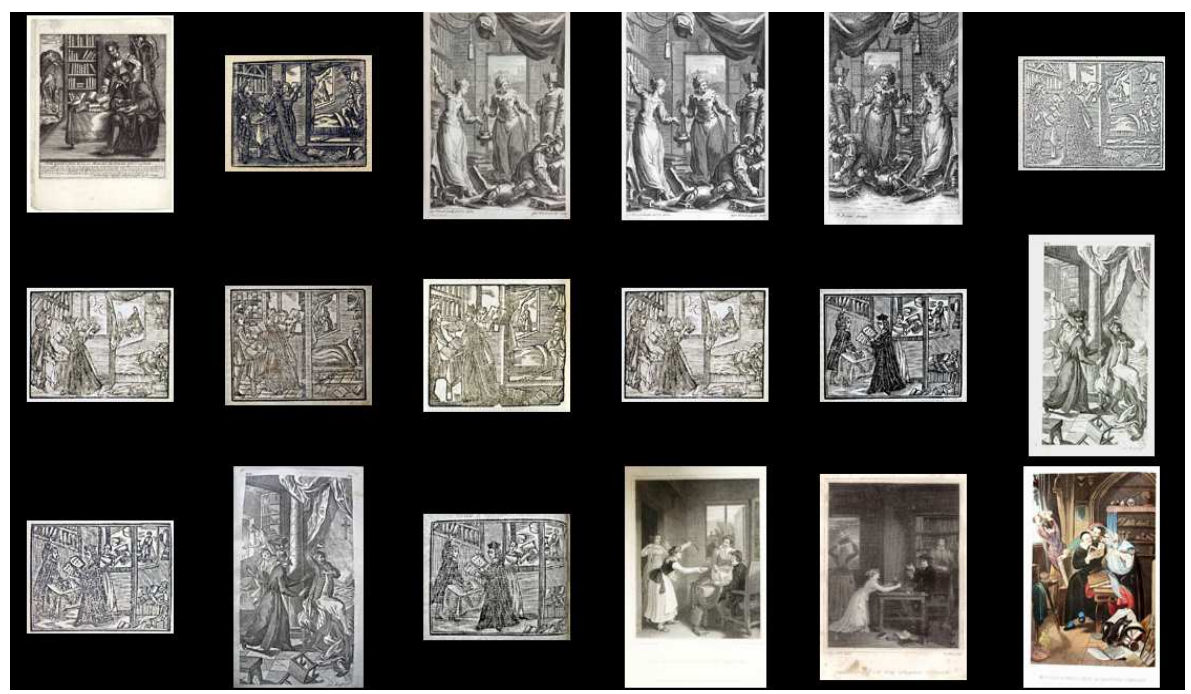

F.3 D. Quixote's library in virtual and chronological images from El Banco de imágenes del Quijote

\footnotetext{
${ }^{13}$ http://www.uclm.es/ceclm/CentenarioQuijote/index.htm

${ }^{14}$ http://www.qbi2005.com/Default.aspx

${ }^{15}$ http://www.centroestudioscervantinos.es/quienes.php?itm $=6.1$
} 
Therefore it seems that the Web has behaved like a mirror of what had already been done on paper (text and picture): in a first stage, it has created a virtual image of what for centuries had extended readers' libraries. Little by little the Websites dedicated to Don Quixote have attempted to meet other requirements so as to transform this static information into something more dynamic. Thus two big challenges are raised for digital readers of Don Quixote: interactivity and conversion of the virtual space of edition into a place for working and not only for consulting.

\section{Don Quixote on the Web $\mathbf{2 . 0}$}

The instigators of the Web 2.0 were the so-called native users, who converted the cyberspace into a space of communication, exchange and interactivity. The character of Don Quixote has also begun to form part of social networks, blogs, Twister, directories, portals and specific Web pages ${ }^{16}$. Some examples are:

An example of how Don Quixote can be published in a collaborative way is Twijote. This is an application with which one intends to publish Don Quixote in the social network Twitter ${ }^{17}$. The introductory words are "En un lugar de la Web de cuyo nombre no quiero acordarme" [In a place of the Web whose name I do not care to remember]. This project aims at creating a digital edition of Cervantes' book structured in 140-character paragraphs, the limit for Twitter messages. 8,000 users are necessary to write the first part of Don Quixote.

http://internality.com/web20/files/mapa-web-20.pdf

http://www.twijote.com/connect.php 


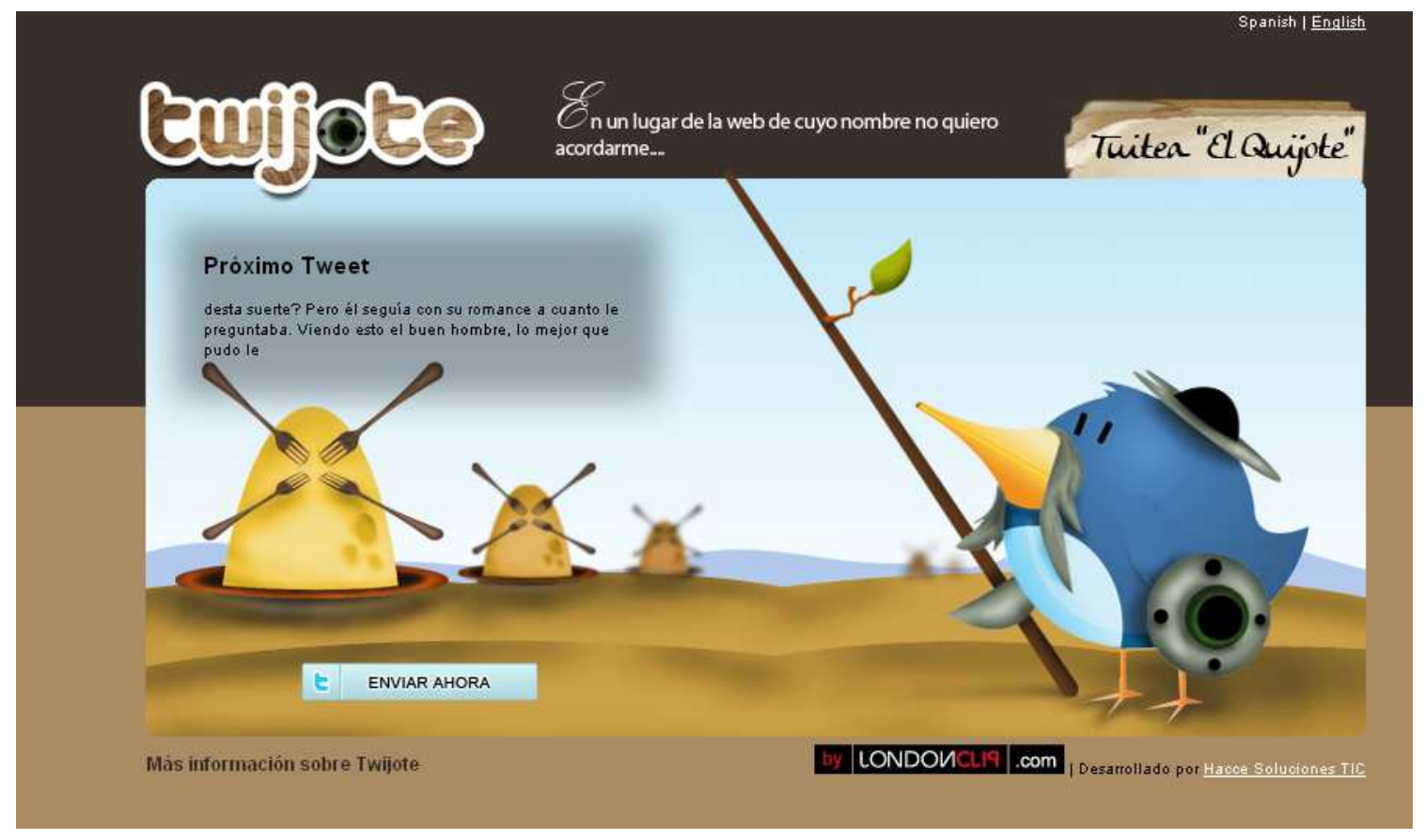

Another interactive Project is the one that is co-directed by Laura Borràs Castanyer (University of Barcelona) and Juan B. Gutiérrez (2010). In the frame of the E-poetry celebrated last May in Barcelona, they presented a [literary GPS] GPS literario. In this case, the initials GPS stand for Global Poetic System. It is a frame for the design and application of locative media for literary projects. Users of this literary GPS can download texts to their mobile phones from literary works where particular spaces are described. Thus, in the first stage, the starting-point is the city of Barcelona and on its beaches we find the adventures of Don Quixote, already known as an errant knight.

Up to now I have had to name and describe the main projects of digitization of the text of Cervantes as much on Web.1 as on Web.2. With this I want to show that the text stays alive online as much at the scientific level, as at the scholarly or recreational ones. But the question which I would really like to answer is: What is the specific mark of these digitizations on our culture? Digital Quixote is a macrospace where texts, pictures and sounds can be gradually interrelated, but does this virtual microspace constitute by itself a macromeme? What meme of Don Quixote is transmitted digitally? 
What is its specific identity as a digital meme? I am going to take an example to explain myself: How does the software created to make concordances on the text influence the interpretation of the text itself? If we look for the word "español" [Spanish] in these concordances, we notice that it appears only half as many times as other terms such as "castellano, gallego, vizcaíno" [Castillan, Galician, Biscaian]. At first glance we realize that the time when Don Quixote is written is not the one of Spanish nationalism. Again, it was romanticism that converted the myth into a national hero. This type of experiment, resulting from technological advances, is nourishing new interpretations about the work. But in order to obtain results through which we could analyze this digital meme of Don Quixote we may have to wait for the celebration of the 5th Centenary of the publication of the work.

\section{Don Quixote as creative pattern}

Nevertheless, the best space of observation of a meme is the creative framework. Poets and narrators are the ones who are best at transmitting values of identity and of the epoch to the literary myths. In this sense, I have found a few examples that can be significant to analyze the path of re-reading of the text.

a.- "Diorama" by Santiago Ortiz ${ }^{18}$ is a work that is constituted taking the web as a metaphor. Its structure is a relational net of concepts, texts, images, interactive applications, links and references in a navigable space. Contents give place to a heap of information and to a reflection regarding language and codes. It particularly identifies three shapes and code uses that operate in backgrounds that are very different but also very close: a code generating life [genetic code], a code generating narration [languages] and a code generating patterns and modes of representation [computer code].

${ }^{18}$ http://moebio.com/santiago/diorama/\# 
Plunging into this mechanized universe gives the impression of being inside the very artificial intelligence, where philosophy, science and technology are finally united recovering a lost paradise. In the part dedicated to "Books", Don Quixote of the Mancha is included. Once you open the hyperlink ten labels unfold themselves. Each of them contains a motto behind which is hidden a passage from Don Quixote whose common denominator is metaliterature. The author focuses your attention on the play of perspectives on which Don Quixote is created. On this very play of perspectives Santiago Ortiz, the digital artist, creates his "Diorama".

b.- The Argentinian digital writer Belén Gaché, also includes a chapter entitled "Escribe tu propio Quijote" [Write your own Don Quixote] in her work Wordtoys ${ }^{19}$. In this work, the authoress calls upon the current necessity to convert ourselves into "somebody" extraordinary and perform a real feat:

\begin{abstract}
Cuando en 1962 Andy Warhol realizó sus Do it yourself flowers, remitía a un producto propio de la cultura de masas: las pinturas Do it yourself, que se había hecho popular en la década del '50. Las mismas consistían en un kit que constaba de dos pinceles y una serie de pinturas numeradas, listas para usar sobre los espacios también numerados de un lienzo. El lema publicitario de estas pinturas era, precisamente, Every man a Rembrandt (cada hombre, un Rembrandt). Mediante la aplicación predeterminada de las pinturas, aparecería la imagen de algún cuadro famoso, de algún paisaje o de alguna naturaleza muerta. Ya no hacía falta ser excepcional, un genio creador para poder pintar un cuadro.
\end{abstract}

The Net gives us this opportunity. In a new way, metareferentiality to the creative act is the key to interpreting this work. In his Don Quixote, the Cervantes-narrator tells us that he is not the author of the work, but that he has found a manuscript written in Arabic, signed by someone called Cide Hamete Benengeli

${ }^{19}$ http://www.findelmundo.com.ar/wordtoys/index.htm 
and that he has had it deciphered by a translator. What Belén Gaché intends is to convert us into "Cervantes". Each one of us can be a Cervantes. Everyone can write their own Don Quixote, as was previously done by Alfonso de Avellaneda in 1614 (who tried to emulate Cervantes' accomplishment) or by Jorge Luis Borges himself in 1944 when writing his tale "Pierre Menard, autor del Quijote" ["Pierre Menard, author of Don Quixote]. But, when we try to write, on this blank page that is offered to us. What happens? Well, write as we may, we cannot get away from the text that Cervantes composed at his time. What happened to Pierre Menard happens to us as well: we cannot escape from the identity of the original text, we can only re-write it, re-interpret it, nourish its meme.
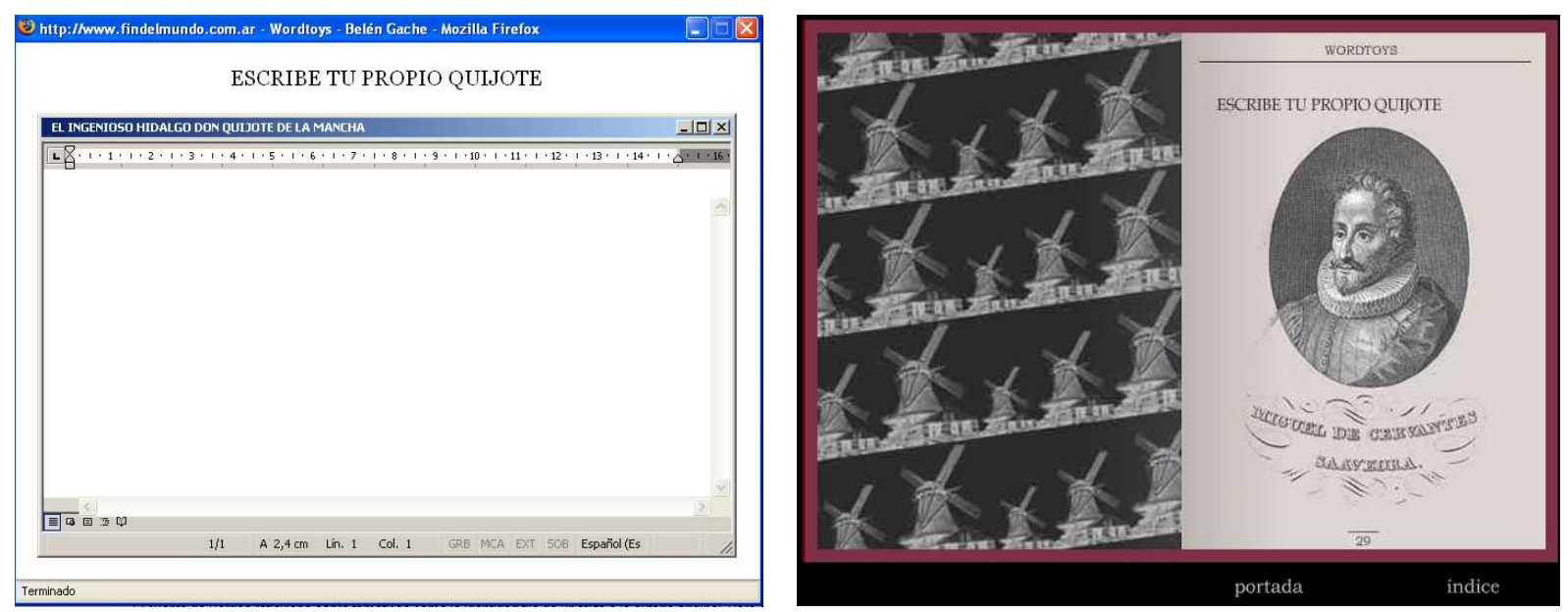

F.4: "Escribe tu propio Quijote" by Belén Gache

But, really, is it not possible to change anything from the heritage of the canon? I think that recently the importance of images ${ }^{20}$ has imposed itself and that plastic artists are the ones who offer us a re-reading in which Don Quixote imitates the signs of our time. It is the case of this comic with which I want to end.

20 http://xkcd.com/556/ 


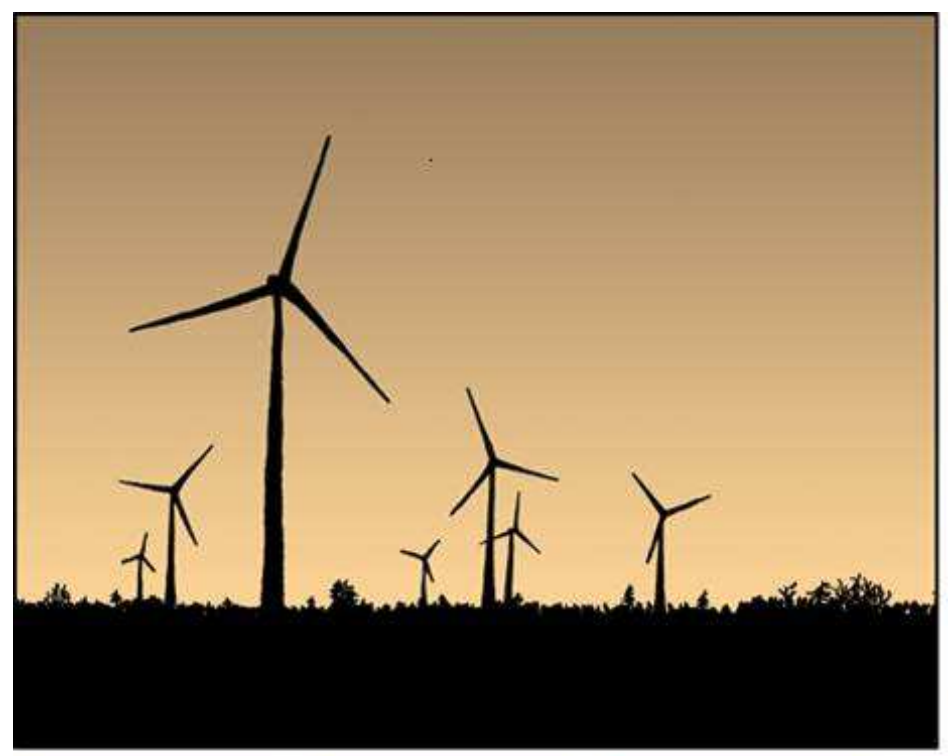

I'M ALL FOR GREEN ENERGY, BUT THOSE TURBINES CREEP ME OUT.

THEY REMIND ME OF WAR OF THE WORLDS, OR THE TRIPOD BOOKS.
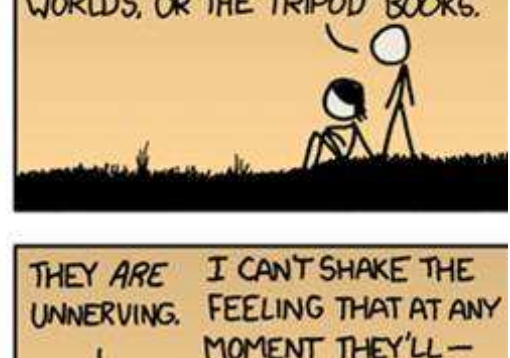

UNNERVING. FEELING THAT AT ANY
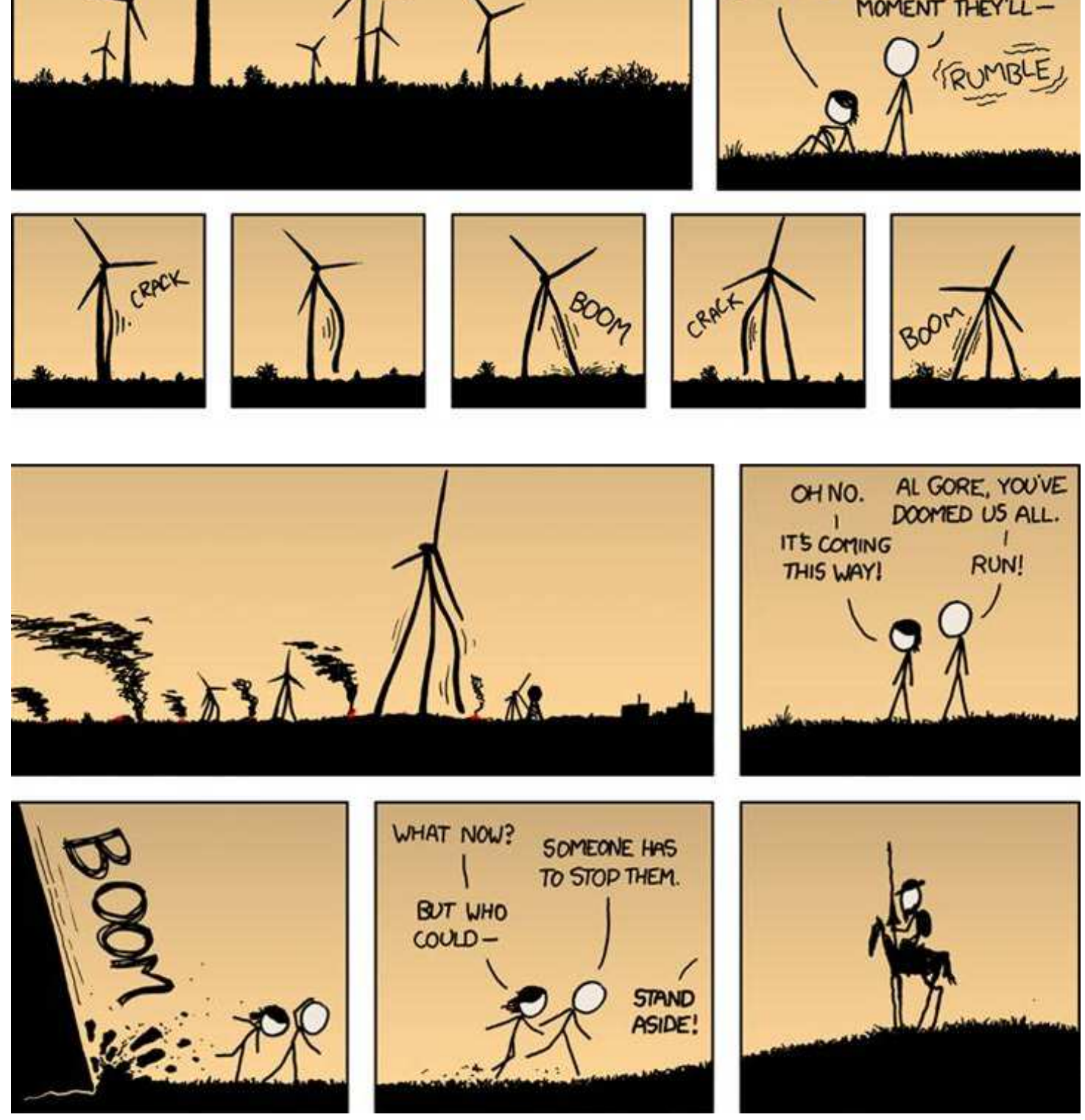

It is the image of an environmentalist D. Quixote, in harmony with the new spirit of our time. But this re-reading of the myth is not derived from the actual virtualization. The strength of all the examples that we have been presenting does not lie so much in the 
originality of their re-reading. I think that within these nearly five years (from the Celebration of the 4th Centenary until today) the Web has been used to imitate the paper pattern. The only difference is that now this pattern remains projected towards a global reader. We will have to wait a few more years to analyze these specific values with which virtualization will impregnate the text. I believe that these values will no longer be subject to the concept of canonization as western "canon". In this sense, Don Quixote is looking for liberty, justice, and defends idealism as heroes from North-American films do. The Web relies on global patterns in which the hero does not impose his strength, the winner is always the plurality, the diversity of readings. And in this Don Quixote is also a real example.

\section{Bibliography}

ALVAR, Carlos, Lucía Megías, J. Manuel et alii. La imagen del Quijote en el mundo. Madrid: Centro de Estudios Cervantinos, 2004. BEN-PORAT, Ziva, "Reader, Text, and Literary Allusion: aspects in the actualization of literary allusions", Ha-Sifrut, 1978, 26, 1-25.

----, "Actualizing Allusions: Hypertext and Cognitive Literary Research", in Amelia Sanz Cabrerizo and Dolores Romero López (eds.), Literatures in the Digital Age. New Castle: Cambridge Scholar Publishing, 2007, 61-81.

BORRÀS, Laura y Benítez Gutiérrez, Juan, "The Global Poetic System. A System of Poetical Positioning", en Jörgen Schäfer, Peter Gendolla (eds.), Beyond the Screen. Transformations of Literary Structures. Interfaces and Genres. Vergag: Transcript, 2010, 56-98.

BUSH, Vannemar, "As We May Think". The Atlantic Monthy. July, 1945. pp. 101-108. 
COLÓN, Isabel, García Carcedo, Pilar, Sanz Cabrerizo, Amelia, "Cruces y encuentros en la primera parte el Quijote", en Don Quijote v promenách casu a prostoru/Don Quijote a través del tiempo y del espacio. Praze: Universita Karlova, 2005, 101-113.

DAWKINS, Richard, El gen egoísta. Barcelona: Labor, 1979.

FUCHS, Bárbara, Mímesis and Empire: the New World, Islam and European Identities. Cambridge: Cambridge University Press, 2001.

----, Passing for Spain. Cervantes and the fictions of identity. Urbana, Chicago: Universidad de Illinois Press, 2003.

GÓMEZ DE CULLÁ, Daniel. La mujer encantada y la mujer real en Don Quijote. Burgos: Edición de autor, 2006.

LENNOX, Charlotte, La mujer Quijote. Madrid: Cátedra, 2004. LUCÍA MEGÍAS, Juan Manuel, Los primeros ilustradores del Quijote, Madrid: Ollero \& Ramos, 2005.

----, Leer el Quijote en imágenes. Madrid: Calambur, 2006.

----, "De las bibliotecas digitales a las plataformas de conocimiento (notas sobre el futuro del texto en la era digital)", en Arbor, Mariña (ed.), Edición crítica e lírica medieval galego-portuguesa. Santiago de Compostela, Universidade, 2010, 45-61.

MONFORTE, Roberto, Las andanzas del Quijote por la literatura rusa. Madrid: Huerga y Fierro Editores, 2007.

MOSTERÍN, Jesús. La cultura humana. Madrid: Espasa Calpe, 2009.

Rubio, Fanny (ed.) El Quijote en clave de mujer/es. Madrid: Editorial Complutense, 2005.

SANZ CABRERIZO, Amelia, "Espacios de la identidad: cruces y encuentros en el Quijote", en Philippe Meunier (dir.), Appartenances. Pertenencias. St. Etienne: Editions du CELEC, 2006, 72-84.

UNAMUNO, Miguel de, Vida de don Quijote y Sancho, según Miguel de Cervantes Saavedra, explicada y comentada. Madrid: Alianza Editorial, 2005. 